\title{
The Teaching of Endurance Running in Physical Education: Representations and Practices of Congolese Teachers
}

\author{
Ngabele Adrien Severin ${ }^{1,2 *}$, Lembe Gorgon', Fernandes Balou Gabin ${ }^{1,2}$, Mabassa David Sylvain ${ }^{1}$, \\ Mviri Hubert César ${ }^{1}$, Massamba Alphonse ${ }^{3}$ \\ ${ }^{1}$ Laboratory of Didactics of Physical and Sports Activities, Institut Supérieur d'Education Physique et Sportive, \\ Université Marien Ngouabi, Brazzaville, Republic of Congo. \\ ${ }^{2}$ UNESCO Chair in Educational Sciences for Central Africa, Ecole Normal Supérieure, Université Marien Ngouabi, Brazzaville, \\ Republic of Congo. \\ ${ }^{3}$ Laboratory of Sport Biosciences, Institut Supérieur d'Education Physique et Sportive, Université Marien Ngouabi, Brazzaville, \\ Republic of Congo \\ Email: *adrienseverinngabele@gmail.com
}

How to cite this paper: Severin, N. A. Gorgon, L., Gabin, F. B., Sylvain, M. D., César, M. H., \& Alphonse, M. (2021). The Teaching of Endurance Running in Physical Education: Representations and Practices of Congolese Teachers. Advances in Physical Education, 11, 395-414. https://doi.org/10.4236/ape.2021.114033

Received: September 15, 2021

Accepted: November 9, 2021

Published: November 12, 2021

Copyright (c) 2021 by author(s) and Scientific Research Publishing Inc. This work is licensed under the Creative Commons Attribution International License (CC BY 4.0).

http://creativecommons.org/licenses/by/4.0/

\begin{abstract}
Endurance running is one of the athletic activities used in the teaching of physical education and sports in Congolese schools. However, observations of teaching practices show that this activity is not included in the other programmed activities. In this context, this article aims to identify and analyse the representations of Congolese physical education teachers, and to identify the obstacles linked to the teaching of endurance running. The results presented are based on research carried out in the three main cities of Congo-Brazzaville. In a cross-sectional survey conducted between February and December 2020, 107 randomly recruited teachers responded to a questionnaire focusing on the teaching of endurance running (professional identity and profile, characteristics of the infrastructure within the school, various pedagogical-didactic aspects of teaching practices). In addition, 10 teachers (experienced; physical education trainers) were interviewed on the basis of intensive clinical interviews. The results show the use of scattered teaching strategies in the teaching of endurance running, explained by the vagueness of their representations of "resistance running", "endurance running", "distance endurance", "duration endurance". This led the teacher to use the duration race, contrary to the institutional recommendations. Hence, it is necessary to improve the teachers' practices and to consolidate the links between the didactic, epistemological and ecological characteristics and the various components of the activity in its teaching in a disadvantaged environment.
\end{abstract}




\section{Keywords}

Representations, Physical Education and Sports, Endurance Running, Learning Obstacle, High School

\section{Introduction}

Physical education (PE) and sports occupy a prominent place in the education system as a teaching discipline from nursery school to university, just like other educational disciplines (Delignières \& Garsault, 1993). Its teaching is based on physical activities and sports (PAS) which contribute to the formation of pupils' personalities, helping them to develop physically, intellectually and morally (Pasco \& Ennis, 2009). Furthermore, PE at all levels of schooling aims at the success of all pupils and contributes, along with other disciplines, to the instruction, training and education of each individual. However, its implementation requires a high level of training for all teachers, improved teaching conditions (facilities, class size, etc.), and substantial timetables allowing for discovery, practice, learning and transformation. It must be possible for each pupil to go further within the school framework so that PE contributes to the acquisition and mastery of the common base and enables pupils to share the values of the Republic.

The work of Roux-Perez (2001) has made it possible to identify a series of elements that reveal the evolution of the discipline. The specific contents of PE reflect continuity and change: continuity of the aims, values and disciplinary objectives, change in the status of the pupil who becomes an actor in his or her learning. In fact, placing the pupil at the centre of educational concerns has led to the transformation of professionals; construction of pedagogical projects, didactic treatment of Artistic, Physical Activities and Sports, reflection on the contents to be taught and on the methods of evaluation, implementation of new pedagogical procedures (differentiation, formative evaluation, contract pedagogy...). This evolution cannot be achieved without the active contribution of teachers.

In Congo-Brazzaville, the physical education program is based on six main areas, namely: locomotion; manipulation; awareness; expression; cooperation and opposition (INRAP, 2005). The application texts of the school law specify the modalities of the use of PAS in the teaching of physical education. The hourly volume allocated to this teaching is 2 hours per week, with one hour per session. In high school, the PSAs included in the program are: gymnastics, soccer, volleyball, handball, basketball and athletics. The athletic activities taught are: sprinting $(100 \mathrm{~m})$, relay races $(4 \times 100 \mathrm{~m})$, endurance races $(800 \mathrm{~m}, 1500 \mathrm{~m}$, $5000 \mathrm{~m}, 10,000 \mathrm{~m}$ ), throws (shot put), jumps (length, triple jump). Each of these activities is taught in 10 hours, that is to say 10 lessons ( 2 theoretical lessons, one introductory lesson, 6 learning lessons, one final lesson). It is in this context that 
endurance running is included among the athletic sports. In high school, this activity is characterised by the economy of the running and the regularity of the speed. The observables of the teaching are related to the way of running, the regularity and the behaviour in the peloton. Several studies are devoted to the teaching of athletic activities around the world (Sheldon, 2003; Trudeau \& Shephard, 2008). In the Congo, several studies relating to athletics have been carried out on didactics, notably the study by Tamba (2009) on the diversity of teaching/learning methods for sprinting $(100 \mathrm{~m})$, and that of Mabassa et al. (2016) on the development of evaluation scales for the sprinting test $(100 \mathrm{~m})$ in the Congolese baccalaureate. However, our experience as PE teachers has shown that the teaching of endurance running is almost scarce. The few teachers who do teach it do not respect the tests chosen by the institutional program. They use the duration endurance race instead of the distance endurance race. Although the concepts are not well defined by National Institute of Pedagogical Action Research (INRAP) in Congo, especially between endurance and resistance running, teachers should teach endurance races in duration and distance as elsewhere, while respecting the distances provided by the program. Furthermore, the observations made about the sidelining of endurance teaching were confirmed by the recent study by Mviri (2018). This author notes that endurance running is retained as a teaching activity in PE in high school by only a few teachers. Although programmed in the first grade by $58.6 \%$ of teachers, endurance running is only taught by $13.3 \%$ of them; however, the knowledge taught is not mastered by the students. In addition, it ranks fourth among the activities carried out (after gymnastics, long jump and relay running), regardless of the levels of study where endurance is programmed as a teaching activity. Its teaching takes place on empty, sandy grounds in most cases. The delimitation of the track is done with studs (not more than 10), the tracing on the ground being done sometimes with a stick. If the inadequacy of learning time and the lack of infrastructure denounced by teachers refocus the problem of teaching this sport activity in Congo, however, don't teachers' representations and attitudes towards teaching endurance running play a role in the implementation of this discipline? In fact, several studies show the need to know the inputs (environment, prerequisites, etc.) in the implementation of efficient teaching/learning strategies likely to promote learning in the discipline (Brousseau, 2004; Cadopi, 1994; Bru, 2007). Among these, the representations that teachers have of the endurance running activity are often cited, particularly the tasks to be carried out.

The representations that teachers make of themselves are very important; they promote the efficient transmission of knowledge and know-how, and the appropriation of motor skills, or on the contrary, hinder them (Abric, 1987). The notion of representation refers to different epistemic fields: philosophy, mathematics, aesthetics, sociology, psychoanalysis and psychology. The approach to the notion of representation takes on the connotation of both content and the function of producing and organising meanings, which can be grasped in discourse, 
attitudes and behaviour. It is therefore presented as a double system of meaning production: election and linking of meanings establishing a coherent reading and integration of reality; organisation of action and decision-making, particularly in professional situations.

As an act by which an object is present or presents itself to the mind, we can then consider representation as "the product and the process of a mental activity by which an individual or a group reconstitutes the reality with which it is confronted and attributes a specific meaning to it" (Abric, 2011: p. 17). It is therefore a reflection, not of the object, but of the complex relations, real or imaginary, objective and symbolic, that the subject has with this object (Abric, 2011).

The study of representations in the teaching process is therefore essential. The $\mathrm{PE}$ teacher must take an interest in this concept of representations, in order to better identify the obstacles that can constitute barriers to learning, which is then fundamental to know and understand them in the framework of our research work. It therefore seemed relevant to us to identify and analyse the representations of Congolese PE teachers on endurance running.

Our research is therefore part of the studies on the social representations of endurance running through the vision of PE teachers and the development of a learning unit for this activity in high school. In order to understand and elucidate the difficulties experienced by PE teachers in teaching endurance running, we asked ourselves the following main question: what are the teachers' representations likely to explain the difficulties encountered in the teaching/learning of endurance running in Congolese high schools? In the light of this questioning, we hypothesis that: the representations of PE teachers through their professional skills, some ecological and institutional factors are at the origin of the exclusion of endurance running among the activities to be taught. The objective of the study is to identify and analyse the representations of PE teachers in Congo on endurance running in physical education, and to identify barriers to activity teaching.

\section{Methods}

The study was carried out in the communes of Brazzaville, Pointe-Noire and Dolisie, the three main cities of Congo. Table 1 shows the distribution of middle

Table 1. Number and percentage of secondary schools by city.

\begin{tabular}{cccc}
\hline & $\begin{array}{c}\text { Public sector } \\
\text { n (\%) }\end{array}$ & $\begin{array}{c}\text { Private sector } \\
\text { n (\%) }\end{array}$ & $\begin{array}{c}\text { Total } \\
\mathbf{n}(\%)\end{array}$ \\
\hline Brazzaville & $18(11)$ & $145(89.0)$ & $163(40.7)$ \\
Pointe Noire & $11(4.9)$ & $213(95.1)$ & $224(56.0)$ \\
Dolisie & $4(30.7)$ & $9(69.3)$ & $13(3.3)$ \\
Total & 33 & 367 & 400 \\
\hline
\end{tabular}

Source: general directorate of physical education and sport for schools and universities, DGEPSSU (2020). 
schools by city.

Given the lack of infrastructure or open space for the practice of physical education, private sector schools were excluded. Consequently, only public schools were retained for this study, i.e. 33 general and technical high schools.

\section{Participants}

The census of teachers working in these 33 high schools, based on data from the sectoral inspectorates of sports and physical education, revealed the data presented in Table 2.

A total of 189 active teachers were counted in the 33 secondary schools selected for the study. However, only teachers who met the following criteria were included in the study: active teachers in the first grade as their teaching level; regular teachers of PE in their school; teaching for at least two years; agreed to participate in the study. The following teachers were excluded from the study: teaching PE for less than two years; temporary teachers; and taught a class other than the first grade.

In the end, 107 teachers met the inclusion criteria. They were distributed as follows: 64 (59.8\%) in Brazzaville, 33 (30.8\%) in Pointe-Noire and 10 (9.4\%) in Dolisie. Table 3 shows the distribution of subjects by gender.

\section{Experimental procedure}

The study was carried out from 3 February to 15 December 2020 and took place in three stages: stage 1, Brazzaville; stage 2, Dolisie; stage 3, Pointe-Noire. This mode of investigation is based on a quantitative and qualitative approach.

Two tools were used for data collection: the questionnaire and the interview.

The choice of the questionnaire is explained by the fact that it does not require any limitation on the expression of the respondent with regard to the strict questions proposed to him, in particular by recourse to items or evocation questions (Abric, 1997). It was therefore chosen for its ease of use and its standardised

Table 2. Distribution of teachers working in high schools by city and sectoral inspectorate.

\begin{tabular}{ccc}
\hline & Effectives (n) & Percentage (\%) \\
\hline Brazzaville & 122 & 64.5 \\
Pointe Noire & 51 & 27.0 \\
Dolisie & 16 & 8.5 \\
Total & 189 & 100 \\
\hline
\end{tabular}

Table 3. Number and percentage of teachers by gender.

\begin{tabular}{cccc}
\hline & $\begin{array}{c}\text { Male } \\
\mathbf{n}(\%)\end{array}$ & $\begin{array}{c}\text { Female } \\
\mathbf{n}(\%)\end{array}$ & $\begin{array}{c}\text { Total } \\
\mathbf{n}(\%)\end{array}$ \\
\hline Brazzaville & $43(67.1)$ & $21(32.9)$ & $64(59.8)$ \\
Pointe Noire & $28(84.8)$ & $5(15.2)$ & $33(30.8)$ \\
Dolisie & $7(70)$ & $3(30)$ & $10(9.4)$ \\
Total & 78 & 29 & 107 \\
\hline
\end{tabular}


nature. The questionnaire, composed of 18 items, was divided into three parts: part 1 , relating to identity of the subjects, gender, seniority, speciality of the teacher at the end of training and professional experience; part 2, devoted to the characteristics of the sports infrastructure and provided information on the presence or absence of tracks and/or open space within the establishments; part 3, whose items dealt with the different aspects of teaching practices; Part 3, whose items dealt with different aspects of teaching practices, including: activity planning, programming and teaching of endurance running, teaching materials, textbooks used and types of evaluation. These were open-ended items, closed-ended items and free-form opinion items.

The closed-ended questions allowed for precise answers, while the open-ended questions were prone to personal evocations. The free-form questions asked teachers directly what they thought about the teaching of endurance running in high school. A pre-survey of $40 \mathrm{PE}$ teachers with a background in PAS survey techniques made it possible to test the questionnaire in order to verify its accuracy and operationality and thus to validate the content in terms of comprehension, degree of acceptability and ease of interpretation of the questionnaires by the respondents. The questionnaire consistency was verified using Cronbach's $\alpha$ index, which was calculated to be 0.83 .

Clinical interviews were conducted with eight high school PE teachers and two teacher-researchers from the Higher Institute of Physical Education and Sport, Marien NGOUABI University, who are in charge of athletics courses. It is a type of interview entirely centred on the person of the interviewee whose most individual and original characteristics are to be explored in depth in order to gather information centred on attitudes towards the teaching/learning of endurance running (Grawitz, 1993). The interviews were conducted in a very free and non-directive manner. The interviews were recorded using an ENET M 50 Digital Voice Recorder (Shanghai, China), with the following characteristics: total recording time, 17,160 minutes; frequency, $16 \mathrm{KHz}$; dimensions, $97 \times 20 \times$ $13.5 \mathrm{~mm}$. This technique allowed the production of linear speeches with moderate inference, where the interactions with the interviewee were oriented and structured by some landmarks in order to collect good quality information.

The 40 questionnaires were distributed after one week. During these visits and contacts with the teachers, they were informed that the anonymity and confidentiality of their answers were guaranteed. For this purpose, a consent form was prepared and sent to them. Respondents were asked to return the completed questionnaire after one week. Out of a total of 40 questionnaires, only 37 questionnaires were completed in full, i.e. a loss of $7.5 \%$.

This preliminary "survey" made it possible to collect a certain amount of information that proved to be relevant.

Construction of the questionnaire

Three concerns governed our task in constructing the questionnaire: the choice of questions and their wording, and the arrangement and organisation of all ques- 
tions, the succession of which made up the questionnaire. With regard to the content of the questions, three types of questions were chosen: factual questions (information on concrete facts of which the respondent is aware); action questions (the subject is asked whether he or she has carried out such and such an act); opinion questions (the subject is asked directly what he or she thinks about such and such a problem).

In Brazzaville, 93 questionnaires were distributed after two weeks. The collection of the questionnaires took 4 months. In the city of Dolisie, 10 questionnaires were distributed in two days and collected in one week.

In the city of Pointe Noire, 37 questionnaires were distributed within two weeks. Out of a total of 140 questionnaires distributed, 107 were fully completed, i.e. a 23.6\% loss. During these different questionnaire distribution periods, contact was made in turn with the heads of the PE departments of the schools included in the study and with the teachers to explain the aims and objectives of the survey. With regard to the latter, the method of filling in the questionnaire was explained to the respondents and they were informed of the confidential nature of the study.

Conduct of the interviews

During the one-hour clinical interview, the interviewee retained the maximum amount of initiative, with the interviewer limiting himself to helping the subject to clarify his thoughts and not to stray into areas that were outside the scope of the survey (Grawitz, 1993). As for the interviewer's interventions, they were not fixed in advance and were made according to the course of the interview. This tool made it possible to collect information about the teachers' opinions on the knowledge associated with the teaching of endurance running, in particular: to identify the difficulties they encounter when teaching endurance running and to understand their origin, to appreciate the teaching programme made available to students at the Higher Institute of Physical Education and Sport.

\section{Variables of the study}

The study related to the representations of PE teachers on the teaching and learning of endurance running, takes into account: the attitudes of teachers based on biological, ecological and didactic aspects. Also, the following variables were studied: 1) dependent variables: the programming of the PAS; the presence of the learning unit of endurance running; the notional contents; the presence of practical material; 2) independent variables: the presence of the track or open space; the speciality chosen at the end of the training.

\section{Statistical analysis of the data}

Analyses were performed using SPSS Statistics V.24.0 (SPSS Inc., Chicago, Il, USA). The chi-square $\left(\chi^{2}\right)$ test was used to establish inference between the variables involved in the study. Spiegel's S-test was used to compare two or more percentages. With regard to the interviews with the teachers, we conducted an inductive analysis of the interview data using conceptualising categories (Paillé 
\& Mucchielli, 2003). The categories reflected representations, expectations, interests, etc., i.e. a set of interacting phenomena. Once this categorisation had been carried out, we attempted, in order to formulate an explanatory hypothesis, to reconstruct the processes resulting from these interactions on the basis of interpretative and speculative work. The significance level of the tests was set at $p$ $<0.05$.

\section{Results}

\subsection{Data from the Questionnaire}

\section{Professional status of respondents}

With regard to the number of years of professional practice as a PES teacher (Table 4), the survey data show that $43 \%$ of the teachers had been teaching for 6 9 years, $32.7 \%$ for ten years or more and $24.3 \%$ for 2 - 5 years; there was no significant difference between the three categories in terms of percentage.

Of the 107 teachers surveyed, 69.2\% $(p<0.05)$ had chosen athletics as their individual sports speciality in their final year of training. However, of the 74 teachers who had chosen athletics, only $12(16.2 \%)$ had chosen to go into greater depth, compared to $83.8 \%(n=62)$ of the teachers who had not gone into greater depth of knowledge and experience in athletics $(p<0.001)$.

Ecological part

The respondents' answers regarding the existence of open spaces in the school and their nature are shown in Table 5.

Analysis of the data in this table shows the existence of open spaces suitable for teaching endurance running: $83.2 \%$ of citations $(p<0.001)$. For most of these open spaces, there was no athletics track $(72.9 \%$ of the citations; $p<0.01)$; however,

Table 4. Professional experience (seniority).

\begin{tabular}{ccc}
\hline & Effectives $(\mathrm{n})$ & Percentage $(\%)$ \\
\hline $2-5$ years & 26 & 24.3 \\
$6-9$ years & 46 & 43 \\
$\geq 10$ years & 35 & 32.7 \\
Total & 107 & 100 \\
\hline
\end{tabular}

Source: field survey.

Table 5. Data on respondents' opinions on the existence and nature of open spaces.

\begin{tabular}{lcc}
\hline & Effective (n) & Percentage (\%) \\
\hline Appropriate space within the institution & 89 & $83.2^{* * *}$ \\
Inappropriate space within the facility & 18 & 16.8 \\
Appropriate space in the vicinity of the facility & 18 & 16.8 \\
Inappropriate space in the vicinity of the facility & -- & -- \\
\hline
\end{tabular}

Source: field survey; Abbreviation: ${ }^{* *}$ significant difference at $p<0.001$. 
it was possible to lay out a track ( $72.9 \%$ of the citations; $p<0.01)$, as shown in Table 6.

The didactic material used in endurance teaching consisted of: decameters (98.8\% of the citations), stopwatches (92.5\%), whistles (91.6\%), studs (90.6\%) and clappers (86.9\%).

Genetic part

Endurance running was included in the schools' annual programme in $92.5 \%$ of cases $(p<0.001)$. Only $75.7 \%$ of the teachers $(p<0.01)$ included endurance running in the PAS to be taught. Even if the activity was scheduled, it was only taught by $39.2 \%$ of the teachers $(p<0.05)$. Of the 42 teachers who taught the lessons associated with endurance running, the learning unit was found in the teaching documents and sheets of only 12 of them (28.6\%; $p<0.01)$. The type of endurance events taught and evaluated by the teachers was disparate (Table 7), with a decreasing order: duration running ( $45.2 \%$ of citations), other unspecified events $(33.3 \%)$ and distance endurance (21.4\%). There was no significant difference between the different citation rates.

With regard to the teachers' responses on the nature of the guidance tools for teaching endurance running that they had, all the teachers had the institution's curriculum book. However, $30 \%$ of them had athletics textbooks and $4.7 \%$ had a pedagogical guide whose nature was not specified.

\subsection{Analysis of the Interview Corpus}

The analysis of the interviews with the 10 respondents (R) made it possible to identify the following themes: the planning of endurance running learning activities, and their management (Table 8). With regard to planning, it should be mentioned that the participants' conceptions of the scope of planning varied

Table 6. Characteristics of the open space track.

\begin{tabular}{ccc}
\hline & Effective (n) & Percentage (\%) \\
\hline Existence of the track & 29 & 27.1 \\
Non-existence of the track & 78 & $72.9^{\star *}$ \\
Possibility to draw a course & 78 & $72.9^{* *}$ \\
\hline
\end{tabular}

Source: field survey; Abbreviation: ${ }^{* *}$ significant difference at $p<0.01$.

Table 7. Type of endurance event used in the assessment.

\begin{tabular}{ccc}
\hline & Effective (n) & Percentage (\%) \\
\hline In distance & 09 & 21.4 \\
In duration & 19 & 45.2 \\
Other evaluations & 14 & 33.4 \\
Total & 42 & 100 \\
\hline
\end{tabular}

Source: field survey. 
considerably. Thus, for some (R02, 03, 08, 09, 10) long-term planning means the whole school year, while for others $(\mathrm{R} 01,05,06,07)$ it refers to the stage. In the same vein, short-term planning is equivalent for many (R01, 02, 04, 05, 07) to the term, for others $(\mathrm{R} 09,10)$ to the learning cycle planned in the month. However, regardless of the meaning of duration, in general, the teaching of endurance running is not included in long-term planning.

In terms of short-term planning, the practices mentioned by the respondents were on a continuum that ranged from no planning at all to detailed planning of content and teaching methods. Some teachers (R01, 02, 07, 10) report a mode of operation based on experience and routine, without any planning, as participant R01 mentions: "It's a bit of instinct. It's homework with the class. We see how far the student can go in the race. If it doesn't work, we back off'. Participants R03, 05, 06 and 09 are in the same vein when they explicitly state that they do not plan, but rather work on the basis of pupils' abilities and spontaneous ideas.

At the opposite pole are those who plan the learning cycle rigorously. For example, R07 plans to an equal extent the content to be learned and the pedagogical means to achieve it:

"It's certain that in planning a lesson, for example in the short term, I'm going to foresee the different modes to reach the pupils. So I'm going to use a lot of the students' possibilities and abilities to develop aerobic capacity.

And the students can ask questions before and after the lesson, discuss".

Teachers who make detailed short-term plans say they take into account a number of factors that can influence student learning. Most often, learning about endurance running would be planned according to students' strengths and weaknesses, but also according to the diagnosed impairments in the intervention plans. These factors would be used to plan the content of the activities: "when I plan, I plan enrichment material for my more able students, faster in the race, the students who are more autonomous" (R05). The organisation of work would largely depend on the same factors:

"I still have my three levels, because we grouped them by level, I know for example this morning I did the reading for my level 3. For them, I wanted them to do a complete run for 12 minutes. Level 2, for them I differentiate according to the requirements of the race that I can give to these pupils" (R09).

Other factors come into play in short-term planning, such as the biorhythm of the pupils, as R10 testifies: "I even go according to the weather, the nature of the climate and the ambient air temperature of the day. In the morning from 7 to 9 my pupils are fresh, available and, as the day progresses, it is more difficult to teach endurance running. This is the case for lessons that have to take place outdoors in the afternoon from 2 to 4 p.m., and my students who need differentiation are very sensitive to this'. Pupils' particular interests can sometimes determine the choice of the type of course to be developed. 
While the previous examples disregard a frontal planning, which tries to take into consideration certain characteristics of the pupils (level of physical aptitude, observed and/or diagnosed abilities, interests, biorhythm), participant R09 puts forward an operation that starts from the pupils' needs:

"We try to take collective time. At the end of each lesson, we call it the lesson review. What was done well, what do we need to work on? What do we have, do you need anything? Some students really need tools to participate fully in the race. Sometimes for the next lesson we take that into account. So we have to get on board in the lesson; we know, it's us who know where we're going, so the pupils have to be at the centre of the motor learning".

In relation to the management of learning situations for endurance running, the practices reported concern various aspects, such as the pedagogical approach for the explanation of concepts related to the teaching of the activity, the type and nature of the tasks, the organisation of the work, the management of the class. Table 8 details and exemplifies these dimensions of practice by the teachers interviewed.

\section{Discussion}

The purpose of this study was to identify and analyze the representations that Congolese physical education teachers have of the teaching of endurance running

Table 8. Piloting of endurance running practices reported by the interviewed teachers (continued).

\begin{tabular}{|c|c|c|c|}
\hline $\begin{array}{l}\text { Aspect concerned } \\
\text { by the practice }\end{array}$ & Practice & Targeted categories of pupils & $\begin{array}{l}\text { Teachers who } \\
\text { mention this use }\end{array}$ \\
\hline \multirow{4}{*}{$\begin{array}{l}\text { Pedagogical } \\
\text { approach }\end{array}$} & \multirow{2}{*}{$\begin{array}{l}\text { Frontal explanations with specific } \\
\text { questioning. }\end{array}$} & -Pupils who have difficulties in the activity. & $02,03,04,06,10$ \\
\hline & & $\begin{array}{l}\text {-Pupils who are diagnosed as being slower at } \\
\text { running, who do not master the prerequisites or } \\
\text { who have difficulties in following the race. }\end{array}$ & $01,05,06,08$ \\
\hline & Varying approaches at all times. & All & $01,03,04,07$ \\
\hline & Strategic teaching. & All, especially students with difficulties. & $03,07,10$ \\
\hline \multirow[t]{2}{*}{$\begin{array}{l}\text { Type and nature of } \\
\text { the task required }\end{array}$} & $\begin{array}{l}\text {-Adaptations to the particular } \\
\text { difficulties of pupils. }\end{array}$ & -Pupils who show difficulties in the activity. & 05,09 \\
\hline & -Segmentation of the task. & -Pupils diagnosed as weak. & $04,07,08$ \\
\hline \multirow{3}{*}{$\begin{array}{l}\text { Organisation of } \\
\text { work }\end{array}$} & -In teams. & All & $03,08,09,10$ \\
\hline & $\begin{array}{l}\text {-Pairing of pupils (strong with } \\
\text { weak). }\end{array}$ & $\begin{array}{l}\text {-Pupils diagnosed as strong, having completed the } \\
\text { race in the diagnostic lesson, pupils with difficulties. }\end{array}$ & $02,08,09,10$ \\
\hline & $\begin{array}{l}\text {-Adapted to the lesson plan and } \\
\text { teaching/learning cycle. }\end{array}$ & All & 02,06 \\
\hline \multirow[t]{2}{*}{$\begin{array}{l}\text { Classroom } \\
\text { management }\end{array}$} & $\begin{array}{l}\text {-Additional individualised } \\
\text { explanations and encouragement. }\end{array}$ & Pupils who present difficulties in the activity. & $02,04,06,07,10$ \\
\hline & -Rephrasing of instructions. & Pupils who present difficulties in the activity & 07 \\
\hline
\end{tabular}


in high school. The results obtained show that among the 107 teachers surveyed, only $39.2 \%(n=42)$ taught endurance running. However, the pedagogical documents related to this teaching were found in only 12 teachers. However, it was noted among the respondents that there was a confusion in the terms "endurance" and "distance endurance", which was at the origin of the disparity in the activities and situations proposed.

The analysis of the results has made it possible to describe the representations that PE teachers in the Congo have regarding the sidelining of the teaching of endurance running in secondary schools and its non-programming among the PASs to be taught. Thus, we propose to characterise these practices, which are supposed to contribute to the emergence of individual and contextual difficulties associated with representations regarding the teaching of this activity.

First of all, the results in Table 4 indicate that the seniority of the Congo's PE teachers does not influence the teaching of endurance running in schools. All subjects encounter the same difficulties, whether they are old or new. Our results go in the same direction as certain authors who question the criterion of seniority as a factor of effectiveness or expertise in teaching PE in particular (Rosado et al., 1998). In fact, the least experienced, despite their recent graduation from training institutes, express the same difficulties as the most senior, while the latter's knowledge may seem obsolete. Thus, our results are in line with those of Rosado et al. (1998) on diagnostic and perception skills. These authors generally show that there are only a few differences between experienced teachers and those entering the profession. Two factors may explain these observations: 1) professional experience stems from routine practice, however, it does not allow for the development of the characteristics of teaching expertise; 2) the emphasis on feedback in university teacher education over the last few years has highlighted the diagnostic and prescriptive aspects that are regularly associated with it. This has led to a number of conflicts, particularly in relation to the issue of teacher expertise, which are influenced by the choice of experts.

For this purpose, Berliner (1979) differentiates five different stages of expertise (novice, advanced beginner, competent teacher, successful teacher and expert) which include various aspects: professional experience, academic training and subject knowledge, cognitive functioning and other less explicit criteria of teaching excellence. In the same sense, Rosado et al. (1998) used four groups according to their professional experience (seniority) and familiarity with the contents taught (specialisation or not in athletics as evidenced by extracurricular practices). On the other hand, other authors (Tochon, 1991), based on a systematic review of the criteria for expertise, propose a more exhaustive list: experience (estimated by the number of years of practice); subject knowledge (determined by the academic level in the discipline); pedagogical knowledge (approximated by the level of the recruitment exam as a teacher); reflective practice (evaluated by participation in action research activities or pedagogical innovations); the ability to make one's knowledge explicit and to formalise teaching practices (evaluated by investment in the training of other teachers: pedagogical 
advice, tutoring, in-service training); the social recognition of expertise (approached by criteria of notoriety and designation or recommendation by peers).

While the use of these cross-referenced criteria constitutes a valid set of precautions, it nevertheless masks a vagueness in the definition of competence or expertise in teaching. This is the rejection of external, objectivable indicators such as student performance, which can be a major source of bias (Durand, 1996). These findings lead us to make use of pre-service training. Our teachers finish their training without the knowledge required to tackle the teaching of endurance running, whereas during their training they are supposed to develop practical skills and knowledge. Indeed, the main anchor of the teaching provided at the only university training institution for PE teachers remains a reasoned intake which is part of the measures supposed to favour the success of all students of pedagogical differentiation in consideration of the individual characteristics of the students but also of the group dynamics. From a temporal point of view, the trainers' intentions accompany the action, in a three-step approach that includes a pre-action phase (the intentions guide the choice of pedagogical and didactic tools to be used), an inaction phase (the intentions give shape to the action in context) and a post-action phase (the intentions give meaning to the action and constitute the starting point for a new cycle). Because of the knowledge provided, the work of Sensevy (2001), taken up by Roux-Perez (2004), reveals that during initial training the beginning teacher should develop a minimum requirement of 7 types of competences: Competence 1: communication in various contexts linked to the teaching profession; Competence 2: the design of teaching and learning situations for the contents to be taught; Competence 3: the management of teaching and learning situations; Competence 4: the evaluation of the progress of learning and the degree of acquisition of competences for the contents to be taught; Competence 5: the ability to plan, organise and supervise the functioning of the class group with a view to promoting pupils' learning and socialisation; Competence 6: commitment to an individual and collective approach to professional development; Competence 7: the choice to act ethically and responsibly in the exercise of one's duties.

However, the teachers surveyed have difficulties in expressing the knowledge acquired during their training. These deficits may be due to the limits of the trainer's action, with the main aim of bringing all students up to a predetermined standard, in accordance with a socially accepted norm, embodied in the learning to be reduced in sports activities within a time frame predetermined by the training programme. However, no rigorous planning is in place at the moment for adjustments in terms of requirements concerning the tasks to be carried out and compensation for the difficulties observed. As a result, the pedagogical strategies used are no longer based on the trainers' in-depth knowledge of the groups and on the reasoned choice of practices considered appropriate to support the learning and success of each student in the groups.

As reported in our results, most of the teachers questioned had chosen athlet- 
ics as their speciality more than gymnastics during their training: $74 / 107 ; 69.2 \%$ versus $30.8 \%$. However, these results are in contradiction with their representations and practices regarding the teaching of endurance running in high school. These respondents with athletics as their speciality do not have any experience of this discipline. Indeed, theoretical knowledge of the activity combined with practice following certification and sporting experience justifies the qualification of specialist teacher, which is not the case for our teachers. While theoretical knowledge is mainly acquired through codified and abstract studies or continuing education (Kennedy, 2002), two categories of knowledge are described among teachers: 1) theoretical, general, proportional, explicable knowledge; 2) practical, specific, non-propositional knowledge (which we refer to here as crafted knowledge) (Durand, 1996). The lack of interaction between the speciality of PE teachers in Congo and the choice of activities to be programmed has already been uncovered by Mviri (2018). Indeed, at the Higher Institute of Physical Education and Sports, training institution for physical education teachers in Congo, the choice of speciality comes down to the validity and achievement (institutional certification) of teaching units. However, in PE to have expertise, additional training at the federal level is required to claim to be a specialist. Moreover, Terrisse (2009) had shown, through research in judo, that the didactic intention of the teacher is strongly influenced by his or her federal (sports) training. The personal knowledge of the teachers surveyed had to be built up since their youth as practitioners of athletic activities or by joining the Congolese Athletics Federation to perfect their knowledge. In the same sense, D. Loizon (2017), based on the teaching of judo according to a clinical didactic approach and an exploratory and comprehensive aim, shows that the personal knowledge of judo specialist teachers was built from their youth throughout the practice of judo. It also highlights the role of the "experiential already there" and its conceptions of teachers and their personal knowledge. For the author, the existence of the "sport experiential already there" sheds light on didactic action (planning and decision-making) while the "conceptual already there" reveals their conceptions of the profession.

Moreover, in the schools of the main cities of Congo, there are hardly any regulation athletics tracks; however, there are open spaces, even in the surroundings of the schools (Table 5 and Table 6). As endurance running does not require the presence of an athletics track except for track competitions for standard events, the presence of an open space is sufficient for the teaching of this PAS. In sub-Saharan African countries and in a context of poor development, it is the teacher's responsibility to mark out and mark the course, specifying the starting point, the number of laps in relation to the event and the line marking the end of the race.

As regards the teachers' knowledge of the material and the institutional programme of the activity, all the respondents claimed to have it. This knowledge, called curricular knowledge, which refers to the knowledge of curricula and related teaching materials, is acquired mainly through institutional policies. It is a 
description of what is expected of teachers. However, teachers often interpret these prescriptions through the filter of their beliefs and values (Kennedy, 2002). In the Congo, respect for institutions makes the programming of endurance racing in all schools dependent on institutional requirements, i.e. curricula in accordance with the official instructions of the Republic of Congo (INRAP, 2005). The answers given by the teachers surveyed also reveal the existence of the necessary didactic material for the teaching of endurance running. Most of the teachers contacted have equipment such as stopwatches, decameters, studs, whistles and clappers in their schools or on their own. However, the availability of this equipment does not improve their practice of endurance running in schools in terms of: the nature of the tasks and their completion, the working methods, the temporal organisation of the work, the didactic material used, the support strategies and the resources available. In short, the difficulty lies at the level of teachers' knowledge.

Moreover, although 81 (75.7\%) teachers had planned endurance running in their lessons in accordance with the official instructions, only 42 (39.2\%) of the respondents had actually taught it. These results confirm the lack of pedagogical knowledge about teaching endurance running among teachers. The teachers' personal pedagogical knowledge, which is strongly "situated" and integrated into the action, then structures their perceptions, actions and understanding in depth. This situated character refers to two ideas: extreme contextualisation and emergence. Pedagogical knowledge is essential for any teacher in order to carry out learning. Calderhead (1996) specifies that this type of knowledge, which is relatively recent, coincides with the development of learning theories and theories relating to child development in the field of psychology. Pedagogical knowledge refers to the illustrations, examples and demonstrations that the teacher uses to teach a subject to his or her students. It is inherent to one of the most valuable skills for teachers (Eurydice, 2003), including physical education teachers (Campos Mesa et al., 2011; Kovač et al., 2008; Romero Cerezo, 2009; Romero Granados \& Campos Mesa, 2010). The insufficiency of this knowledge leads teachers to make a choice about which PSAs to teach and to abandon those that seem to be difficult for them, as the interview data show (Table 8). The lack of pedagogical knowledge then justifies the teachers' reluctance to implement this activity in their teaching, hence their abandonment behaviour.

It is in this context that $30(28 \%)$ teachers did not present the endurance running learning unit. No conceptual framework for the teaching of endurance running was found in their teaching documents, thus revealing the lack of chronological lessons in their teaching strategies and the absence of objectives. Only 12 (11.2\%) teachers presented a non-coherent learning unit. However, the examination of their documents for these learning units made it possible to note that no details were given on the content, duration or work sequences. However, programming in PE "is the necessary organisation of work in time and space, which best promotes the achievement of the set objectives (cycle, duration, pro- 
portion, etc.)" (INRAP, 2005). It is a tool to ensure that each student acquires skills through different areas of physical and artistic activities. Therefore, in our work, the lack of knowledge of the activity did not make it easier for the respondents to make a cyclical distribution of endurance. The lack of basic knowledge related to the teaching of endurance running does not facilitate the planning of this activity. PE teachers should therefore possess specific basic knowledge of skills that include: planning skills, implementation skills, social skills, and motivational skills (Stojanović \& Zdravkovic, 2012; Abu-Jameh, 2013). Tul et al. (2015) argued that in order to deliver a quality physical education lesson, teachers need to master four skills, including task design, task presentation, classroom management, and instructional guidance. Teachers' ignorance of endurance running may then be related to the lack of professional skills of these practitioners, an observation that is related to the interview data (Table 8). Planning is defined by subject-specific competences of an instrumental type representing basic professional knowledge in the field of physical education and sport (ANECA, 2004; Campos Mesa et al., 2011; Romero Cerezo, 2009; Romero et al., 2011; Romero Granados \& Campos Mesa, 2010). According to Delignières and Garsault (1993), competence is a structured and coherent set of resources, which enables one to be effective in a social field of activity. These authors think that competences are complex acquisitions that must finalise a teaching cycle by integrating the knowledge that has been acquired. To be competent in $\mathrm{PE}$ is then to be able to adapt in a relevant way to the varied situations of physical practices (Delignières, 2012).

Furthermore, it appears from Table 7 that 9 out of 42 teachers involved in teaching endurance running taught distance endurance and 19 (45.2\%) used duration endurance while not following the programme. Our results consolidate the observations of research conducted within the framework of the cognitivist approach, which was more interested in teachers' thoughts and knowledge and in the information processing processes underlying classroom actions (Durand, 1996). This approach considers that an individual's actions are closely related to previously acquired knowledge available within their cognitive system. Similarly, these teachers use endurance in duration, which does not exist in the PE curriculum in Congo. This attitude expresses the beliefs and knowledge that teachers have about endurance running. Although the texts offer guidelines to be followed, their deafness can theoretically lead to perverse behaviour, particularly in terms of adaptation in the field. We did not measure this aspect but it is likely that the teachers' attitudes observed here are part of their justification. We also observed that $33.4 \%$ of the teachers evaluated in an anarchic manner and $45.2 \%$ of the teachers evaluated using endurance in duration (Table 7). The diversity of methods observed here undoubtedly testifies to the lack of consensus in pedagogical practices among teachers and the lack of mastery of the PAS (endurance running). It is also worth noting the lack of a scale, contrary to other PASs such as sprinting, jumps and throws, where scales exist on a national level. 
Finally, as regards the books and other teaching materials used in the teaching of endurance running, all the teachers surveyed have their programme book, which only gives the main lines. Nevertheless, 31 (30\%) teachers used other textbooks to deepen their knowledge and 5 (4.7\%) teachers claimed to have a teaching guide. However, reading the manuals did not lead to improvements in the acquisition of knowledge of the activity and the development of the endurance race learning unit. However, consulting the manuals should promote the acquisition of new knowledge and facilitate the teaching of endurance running.

Nevertheless, Elbaz (1981) states that teachers' practical knowledge is partly derived from their theoretical knowledge of the subject as well as knowledge of child development and learning theories. In sum, our results, which are contrary to those of Elbaz, reveal that it would be appropriate to apply a new programme for teaching endurance running at the PE teacher training institute in Congo.

\section{Limitations of the Study}

This type of study, which we conducted just before the COVID-19 confinement of the populations of the three cities involved in the experimental work and which is not found in any recent survey in sub-Saharan black Africa, does however have some methodological limitations. The study involved 107 teachers of both sexes living in the communes of the said towns. This sample is undoubtedly not representative of the population of PE teachers in the Congo; moreover, our data did not take into account the specificity of gender in their analysis. It is therefore impossible to generalise these results to the whole country, especially in rural areas where the difficulties encountered in teaching physical education are greater. However, these limitations do not affect the power of our observations. Finally, with regard to the credibility of the results, the strength of our method lies in the procedure for recruiting the respondents, based on voluntary adhesion, which offers more guarantees for the accuracy and reliability of the responses.

\section{Conclusion}

This contribution is part of the effort to feed the reflection around the practice of endurance running in secondary schools in disadvantaged areas in poor developing countries. Despite the fact that decision-makers are talking about giving it a prominent place, our results show that this athletic activity is little used by PE teachers in black African environments, particularly in the French-speaking countries of Central Africa including Congo-Brazzaville. The explanatory hypothesis formulated in connection with this reserve of teachers to implement this discipline in the practice of PE concerns mainly the conceptual vagueness, the lack of training and the skills of the teachers in a context where the implementation of this activity would imply structural changes of the teacher's activity. This text used questionnaire and teacher interview data without exploiting data from the explanatory approach (classroom observation and explanatory interview). The 
analysis of the data relating to the observed practices will make it possible to validate and qualify certain theoretical propositions presented in this article. Furthermore, an in-depth analysis of each case will allow us to consolidate the links between the epistemological perspectives and the characteristics of the practices implemented in the teaching of endurance running in disadvantaged areas.

\section{Conflicts of Interest}

The authors declare no conflicts of interest regarding the publication of this paper.

\section{References}

Abric, J.-C. (1987). Coopération, compétition et représentations sociales. Delval.

Abric, J.-C. (1997). Les représentations sociales: Aspects théoriques. In J.-C., Abric (Ed.), Pratiques sociales et représentations (pp. 11-37). Presses Universitaires de France.

Abric, J-C. (2011). Pratiques sociales et représentations. Presses universitaires de France.

Abu-Jameh, M. (2013). The Role of Educational Supervisors in Improving the Efficiencies of Sport Education Teachers in Gaza Governorates' Public Schools in Light of Total Quality Standards. Unpublished Master Thesis, Al-Azhar University.

ANECA (Agencia Nacional de Evaluacion de la Calidad y Acreditation) (2004). Propuesta de Titulo de Grado En Ciencas de la Actividad Fisica y del Deporte [Proposal for the Title of the Graduate in the Physical Activity and Sport Science]. https://www.aneca.es/var/media/150296/libroblanco_deporte_def.pdf

Berliner, D. C. (1979). Tempus Educare. In P. L., Peterson, \& H. J., Walberg, (Eds.), Research on Teaching (pp. 52-60). McCutchan Publishing.

Brousseau, G. (2004). Les représentations: Etude en théorie des situations didactiques. Revue des Sciences de l'Education, 30, 241-277. https://doi.org/10.7202/012669ar

Bru, M. (2007). Vers une appréhension de la dynamique des pratiques d'enseignement, entrevue réalisée par Yves Lenoir (To the Apprehension of Teaching Practice Dynamism, an Interview Made by Yves Lenoir). Formation et Profession, 13, 7-13.

Cadopi, M. (1994). Sportif et danseur: Représentations pour l'action chez de jeunes pratiquants. Enfance, No. 2-3, 247-263. https://doi.org/10.3406/enfan.1994.2103

Calderhead, J. (1996). Teachers: Beliefs and Knowledge. In D. C., Berliner, \& R. C., Calfee (Eds.), Handbook of Educational Psychology (pp. 709-725). Macmillan Library Reference USA; Prentice Hall International.

Campos Mesa, M. C., Ries, F., \& Del Castillo, O. (2011). Analysis de las competencias adquiridas y utilizadas por los ERINO agresados maestros en educaciòn Fisica [Analysis of the Competences Acquired and Used by Graduated Teachers in Physical Education]. Revista Internacional de Cencias del Deporte, 7, 216-229.

https://doi.org/10.5232/ricyde2011.02405

Delignières, D. (2012). EPS et santé: Nouvelles pratiques ou nouvelles conceptions? International Congress "Health and Physical Education: One Pretext, Diverses Realities", Strasbourg, 28-30 mars, p 43.

Delignières, D., \& Garsault, C. (1993). Objectifs et contenus de l'EPS: Transversalité, utilité sociale et compétence. Revue EPS, 242-9-13.

DGEPSSU (Direction Générale de l'Education Physique, du Sport Scolaire et Universitaire) 
(2020). Rapport sur les statistiques des établissements scolaires du cycle secondaire au Congo, année 2019. Direction Générale de l'Education Physique, du Sport Scolaire et Universitaire.

Durand, M. (1996). L'enseignement en milieu scolaire. Presses Universitaires de France.

Elbaz, F. (1981). The Teacher's "Practical Knowledge": Report of a Case Study. Curriculum Inquiry, 11, 43-71. https://doi.org/10.1080/03626784.1981.11075237

Eurydice (2003). Defining Competences and Curriculum. European Reference Points for the Teaching Profession. Prepared by Eurydice for Study Visit (England, April 2003).

Grawitz, M. (1993). Méthodes des sciences sociales. Dalloz

INRAP (Institut National de Recherche et d'Action Pédagogique) (2005). Livre programme des enseignements de l'éducation physique et sportive. Institut National de Recherche et d'Action Pédagogique.

Kennedy, A. K. (2002). Physical Education Class and Body Image Perception: Are They Related? The Physical Educator, 76, 467-484.

https://doi.org/10.18666/TPE-2019-V76-I2-8766

Kovač, M., Sloan, S., \& Starc, G. (2008). Competences in Physical Education Teaching: Slovenian Teachers' Views and Future Perspectives. European Physical Education Review, 14, 299-323. https://doi.org/10.1177/1356336X08095668

Loizon, D. (2017). La didactique clinique comme mode d'accès aux savoirs des enseignants en ÉPS: Le cas de l'enseignement du judo. Nouveaux Cahiers de la Recherche en Education, 20, 61-78. https://doi.org/10.7202/1049397ar

Mabassa, D. S., Itoua Okemba, J., Tamba, V., \& Massamba, A. (2016). Elaboration de barèmes d'évaluation de l'épreuve de course sur 100 mètres au baccalauréat congolais: Influence des référents biométriques. Les Cahiers de la Chaire, 2, 76-91.

Mviri, H. C. (2018). Problématique de l'enseignement de l'Education Physique et Sportive dans les établissements secondaires et supérieur de Brazzaville: Formation, planification et absentéisme. Thèse en doctorat en sciences de l'éducation, Chaire Unesco, Université Marien Ngouabi.

Paillé, P., \& Mucchielli, A. (2003). L'analyse qualitative. A. Colin

Pasco, D., \& Ennis, C. D. (2009). Les orientations de valeur des enseignants: Une revue de question en éducation physique. Science et Motricité, No. 66, 85-112. https://doi.org/10.3917/sm.066.0085

Romero Cerezo, C. (2009). Definiciòn de mòdulos y competencias del maestro con menciòn en Educaciòn fisica [Modules and Competences of the Physical Education Teacher]. Revista Internacional de Medicina y Ciencas de la Actividad Fisica y el Deporte, 9, 179-200. http://cdeporte.rediris.es/revista/revista34/artcompetencias124.htm

Romero Granados, S., \& Campos Mesa, M. C. (2010). Los egresados de magisterio especialistas de educaciòn fisica y sus competencias [The Higher Education Graduates of Physical Education Teachers and Their Competences]. Journal of Sport and Health Research, 2, 167-182.

Romero, R., Sanchez, Z., Romero Rodriguez, M. N., \& Martinez Lopez, E. J. (2011). Importancia de las competencias profesionales de los Maestros en Educaciòn Fìsica expresadas por los estudiantes [Importance of the Professional Competences of the Primary Teachers in Physical Education Expressed by the Students]. Retos. Nuevas tendencias en Educaciòn Fisica, Deporte y Recreaciòn, 19, 62-68.

Rosado, A., Sarmento, P., \& Piéron, M. (1998). Compétences de diagnostic et de prescription chez les enseignants de divers degrés d'expertise. In C. Amade Escot, J. P. Barrué, F. Bos, M. Durand, \& A. Terrisse (Eds), Recherches en EPS: Bilan et perspectives (pp. 
145-154). Editions Revue EPS

Roux-Perez, T. (2001). Des processus de construction de l'identité professionnelle des enseignants d'EPS: entre appartenance au groupe, expériences professionnelles singulières et recompositions identitaires à l'échelle du temps. Thèse de $3^{\circ}$ cycle en Sciences de l'Education non publiée, Université de Nantes.

Roux-Perez, T. (2004). L'identité professionnelle des enseignants d'EPS: Entre valeurs partagées et interprétations singulières. STAPS, No. 63, 75-88.

https://doi.org/10.3917/sta.063.0075

Sensevy, G. (2001). Modèles de l'action du professeur: nécessités, difficultés. In A. Mercier, G. Lemoyne, \& A. Rouchier (Ed), Le génie didactique (pp. 209-231). De Boeck Université.

Sheldon, S. (2003). Linking School, Physical Education Practicing and Evaluation of Physical Capacities in Urban High Schools/Achievement on State Tests. The Urban Review, 35, 149-165. https://doi.org/10.1023/A:1023713829693

Stojanović, S., \& Zdravković, D. (2012). The Self-Assessment of Personal Competences of Physical Education Teachers. Facta Universitatis-Series: Physical Education and Sport, 10, $141-149$.

Tamba, V. (2009). Diversité des méthodes d'enseignement et apprentissage de la course de vitesse dans les classes pléthoriques congolaises. Mémoire de DEA en Education Physique, Université Pédagogique de Kinshasa.

Terrisse, A. (2009). La didactique clinique en EPS. Origine, cadre théorique et recherches empiriques. In A, Terrisse (Ed.), Didactique clinique de l'éducation physique et sportive (EPS): Quels enjeux de savoirs (pp. 13-31)? De Boeck Supérieur.

Tochon, F. V. (1991). Les critères d'expertise dans la recherche sur les enseignants. Mesure et Evaluation en Education, 14, 57-81.

Trudeau, F., \& Shephard, R. J. (2008). Physical Education: School Physical Activity, School Sports and Evaluation of Academic Performance. International Journal of Behavioral Nutrition and Physical Activity, 5, Article No. 10.

https://doi.org/10.1186/1479-5868-5-10

Tul, M., Leskosek, B., Jurak, G., \& Kovac, M. (2015). Perceived Importance of Slovenian Physical Education Teachers' Professional Competencies. Hacettepe Egitim Dergisi, 30, 268-281. 